\title{
PENGARUH PENDIDIKAN, PENDAPATAN DAN JUMLAH ANGGOTA KELUARGA TERHADAP PENGELUARAN KELUARGA KECAMATAN BATANG ANAI
}

\author{
Oleh: \\ Mitahul Jannah $^{1}$, Afdhal $^{2}$ \\ Fakultas Ilmu Sosial Universitas Negeri Padang \\ Email :jannahmiftahul28@gmail.com
}

\begin{abstract}
ABSTRAK
Penelitian ini bertujuan untuk menganalisis pengaruh Pendidikan, Pendapatan dan Jumlah Anggota Keluarga terhadap Pengeluaran Keluarga. Data yang digunakan dalam penelitian ini adalah data primer yang diperoleh dari hasil wawancara dengan panduan kuesioner atau angket. Jumlah sampel yang dipakai adalah $99 \mathrm{KK}$, diambil menggunakan metodeproporsional random sampling. Teknik analisis yang digunakan dalam penelitian ini adalah uji statistik dengan metode regresi linear berganda dan uji hipotesis menggunakan uji $\mathrm{F}$ dan uji t, namun sebelum melakukan uji hipotesis dilakukan uji asumsi klasik terlebih dahulu. Hasil penelitian menunjukkan bahwa variabel pendidikan dan pendapatan berpengaruh positif dan signifikan terhadap pengeluaran keluarga. Serta variabel jumlah anggota keluarga berpengaruh positif dan tidak signifikan terhadap pengeluaran keluarga. Variabel yang memiliki pengaruh paling dominan terhadap pengeluaran adalah variabel pendapatan. Dari penelitian ini diperoleh nilai $\mathrm{R}^{2}$ sebesar 0.398 , hal tersebut berarti bahwa $39.8 \%$ variabel pengeluaran keluarga dapat dijelaskan oleh variabel independen nya yaitu pendidikan, pendapatan dan jumlah anggota keluarga. Sisanya yaitu $60.9 \%$ dijelaskan oleh variabel-variabel yang lain diluar model atau di luar variabel.
\end{abstract}

Kata Kunci : Pendidikan, Pendapatan, Jumlah Anggota Keluarga dan Pengeluaran

\section{ABSTRACT}

This study aims to analyze the effect of Education, Income and Number of Family Members on Family Expenditures. The data used in this study are primary data obtained from interviews with questionnaire or questionnaire guidelines. The number of samples used was 99 households, taken using the proportional random sampling method. The analysis technique used in this study is a statistical test with multiple linear regression methods and hypothesis testing using the F test and t test, but before conducting the hypothesis test the classical assumption test is done first. The results showed that education and income variables had a positive and significant effect on family expenses. And the variable number of family members has a positive and not significant effect on family expenses. The variable that has the most dominant influence on expenditure is the income variable. From this study an R2 value of 0.398 was obtained, which means that $39.8 \%$ of the family expenditure variable can be explained by the independent variables namely education, income and the number of family members. The remaining $60.9 \%$ is explained by other variables outside the model or outside the variables.

Keywords: Education, Income, Number of Family Members and Expenditures

\footnotetext{
${ }^{\mathbf{1}}$ Mahasiswa Program Studi Pendidikan Geografi

${ }^{2}$ Dosen Jurusan Geografi Fakultas Ilmu Sosial Universitas Negari Padang
} 


\section{PENDAHULUAN}

Undang-undang Nomor 10 tahun 1992, keluarga sejahtera adalah keluarga yang dibentuk berdasarkan atas perkawinan yang sah, mampu memenuhi kebutuhan hidup material, spiritual yang layak, bertakwakepada Tuhan yang Maha Esa, memiliki hubungan yang serasi, selaras dan seimbang antar anggota keluarga dengan masyarakat dan lingkungan.

Kesejahteraan keluarga dapat dilihat dari konsumsi dan pengeluaran keluarga. Keluarga dengan kesejahteraan yang baik mempunyai persentase pengeluaran pangan lebih kecil di banding keluarga dengan kesejahteraan rendah. Jika dikaitkan dengan teori kebutuhan maka pangan merupakan kebutuhan paling utama (Rambe, 2008 dalam Widyaningsih Erni).

Pengeluaran keluarga merupakan belanja yang dilakukan oleh keluarga untuk membeli berbagai kebutuhan dalam satu tahun tertentu. Pengeluaran konsumsi dimana pengeluaran yang dilakukan oleh seluruh anggota keluarga dalam perekonomian tergantung pada pendapatan yang diterima.

Alokasi atau struktur belanja keluarga adalah untuk kebutuhan pangan dan bukan pangan, kebutuhan pangan meliputi sumber karbohidrat, protein, vitamin/mineral serta kebutuhan pangan lainnya. Kebutuhan bukan pangan meliputi pendidikan, pakaian, perumahan, transportasi, rekreasi, kegiatan sosial, listrik, air minum, dan minyak tanah (BPS, 2009).

Dalam hal ini peneliti akan menggunakan 3 variabel untuk menganalisis seberapa besar pengaruh variabel terhadap pengeluaran keluarga yaitu pendidikan, pendapatan dan jumlah anggota keluarga.

Tabel 1 Rata-rata pengeluaran per kapita sebulan menurut kelompok barang (rupiah), 20122016

\begin{tabular}{lllllll}
\hline & $\mathbf{2 0 1 2}$ & $\mathbf{2 0 1 3}$ & $\mathbf{2 0 1 4}$ & $\mathbf{2 0 1 5}$ & $\mathbf{2 0 1 6}$ & Jumlah \\
\hline Pangan & $394.350,64$ & $434.291,63$ & $455.098,09$ & $472.427,92$ & $537.236,03$ & $\mathbf{2 . 2 9 3 . 4 0 4 , 3 1}$ \\
\hline $\begin{array}{l}\text { Bukan } \\
\text { Pangan }\end{array}$ & $302.071,08$ & $334.154,48$ & $354.417,73$ & $422.275,38$ & $447.788,50$ & $1.860 .707,17$ \\
\hline Jumlah & $696.421,72$ & $768.446,11$ & $808.515,82$ & $894.703,3$ & $985.024,53$ & $4.154 .111,48$ \\
\hline
\end{tabular}

Sumber :http://sumbar.bps.go.id

Berdasarkan tabel 1 diatas dapat dilihat bahwa pengeluaran untuk pangan dan bukan pangan mengalami peningkatan. Pengeluaran untuk makanan lebih rendah dibandigkan pengeluaran bukan pangan.
Penelitian dilakukan di Kecamatan Batang Anai, Kabupaten Padang Pariaman. Kecamatan Batang Anai merupakan Kecamatan yang memiliki jumlah penduduk tertinggi dibandingkan kecamatan lain di Kabupaten Padang Pariaman, selain itu Kecamatan ini merupakan daerah pinggiran Kabupaten 
namun memiliki karakteristik unik. Kecamatan ini bisa di istilahkan rural urban fridge dimana suatu daerah pinggiran yang mempunyai ciri-ciri campuran antara kehidupan kekotaan dan kedesaan. Perkembangan daerah ini ditandai dengan berkembangnya kawasan permukiman baru serta padatnya permukiman lama. Semakin banyaknya penduduk baru, hal ini mengakibatkan interaksi antar masyarakat semakin meningkat salah satunya peningkatan perekonomian masyarakat.

Karakteristik daerah ini kemungkinan akan mempengaruhi besarnya pengeluaran keluarga sehingga menarik untuk dilakukan penelitian Pengaruh Pendidikan, Pendapatan dan Jumlah Anggota Keluarga terhadap Pengeluaran Keluarga. Dari latar belakang diatas, maka dapat diambil suatu rumusan masalah antara lain 1) Apakah ada pengaruh tingkat pendidikan terhadap pengeluaran keluarga? 2) Apakah ada pengaruh pendapatan terhadap pengeluaran keluarga? 3) Apakah ada pengaruh jumlah anggota keluarga terhadap pengeluaran keluarga? 4) Apakah tingkat pendidikan, pendapatan dan jumlah anggota keluarga secara bersamaan berpengaruh terhadap pengeluaran keluarga?

\section{METODE PENELITIAN}

Berdasarkan masalah yang diteliti dan tujuan yang akan dicapai dalam penelitian ini, maka penelitian ini menggunakan penelitian deskriptif kuantitatif. Hal ini diharapkan penelitian ini mampu mendeskripsikan secara sistematis, faktual, dan aktual mengenai fakta-fakta dan sifat populasi tertentu secara detail (A.Muri Yusuf,2013).

Rancangan penelitian yang dilakukan menggunakan rancangan preexperiment yaitu the one shot case study yaitu rancangan ini hanya melibatkan satu kelompok atau satu kejadian pada periode waktu tertentu. Dengan demikian tidak ada kelompok control sebagai bandingan dari kelompok eksperimen. (A. Muri Yusuf, 2013).

Hipotesis yang diajukan yaitu : 1 . Terdapat pengaruh positif antara faktor pendidikan dengan pengeluaran keluarga, 2. Terdapat pengaruh positif antara faktor pendapatan dengan pengeluaran keluarga, 3. Terdapat pengaruh positif jumlah anggota keluarga dengan pengeluaran keluarga, dan 4. Terdapat pengaruh pendidikan, pendapatan dan jumlah anggota keluarga secara bersama-sama terhadap pengeluaran keluarga.

Penelitian ini mengambil data primer pada responden atau sampel melalui wawancara yang dipandu dengan kuesioner. Pengambilan sampel berdasarkan pada keluarga yang ada di Kecamatan Batang Anai yang di pilih secara proportional random sampling dimana jumlah sampel pada masingmasing nagari sebanding dengan jumlah keluarga pada Kecamatan Batang Anai.

Untuk mendukung analisis peneliti maka dibutuhkan data sekunder, data sekunder diperoleh dari data-data yang diterbitkan oleh BPS, serta instansi atau kantor wali nagari yang bersangkutan sesuai dengan data yang dibutuhkan. 
Populasi dalam penelitian ini adalah semua keluarga yang ada di kecamatan Batang Anai, yaitu sebanyak
10.388 KK pada tahun 2018. Untuk lebih lengkapnya dapat dilihat dalam tabel sebagai berikut:

Tabel 2 Jumlah penduduk per rumah tangga menurut nagari

\begin{tabular}{ccc}
\hline No & Nagari & Jumlah KK \\
\hline $\mathbf{1}$ & Ketaping & 2.778 \\
\hline $\mathbf{2}$ & Kasang & 3.174 \\
\hline $\mathbf{3}$ & Buayan & 900 \\
\hline $\mathbf{4}$ & Sungai Buluh & \\
\hline $\mathbf{5}$ & Sungai Buluh Selatan & \\
\hline $\mathbf{6}$ & Sungai Buluh Barat & 3.536 \\
\hline $\mathbf{7}$ & Sungai Buluh Timur & \\
\hline $\mathbf{8}$ & Sungai Buluh Utara \\
\hline \multicolumn{3}{|c}{} \\
\hline
\end{tabular}

Sumber : BPS Kabupaten Padang Pariaman 2018

Berdasarkan tabel diatas, jumlah keluarga di Kecamatan Batang Anai $10.388 \mathrm{KK}$, se lanjutkan untuk menentukan sampel digunakan rumus Slovin dengan nilai $\mathrm{e}=10 \%$ atau 0.1 , sehingga dihasilkan $99 \mathrm{KK}$ atau sampel untuk Kecamatan Batang Anai. Untuk mendapatkan di masing-masing nagari digunakan rumus proportional random sampling yaitu :

Sampel pernagari

$$
=\frac{\text { jumlah nagari }}{\text { jumlah total }} \times \text { besar sampel }
$$

Untuk mengetahui apakah hipotesis yang diajukan diterima atau ditolak perlu dilakukan uji asumsi klasik terlebih dahulu. Analisis yang dilakukan adalah Uji Asumsi Klasik, dan Uji Hipotesis dengan Regresi Linear berganda. Untuk melakukan pengolahan data di gunakan SPSS versi 16.0. Analisis Regresi linear berganda yang baik adalah memenuhi semua uji asumsi klasik atau uji persyaratan terlebih dahulu.

\section{HASIL}

Sebelum melakukan uji regresi linear berganda, harus dilakukan uji persyaratan analisis terlebih dahulu. Regresi yang baik memenuhi semua uji persyaratan yang diajukan yaitu, uji normalitas, multikolinearitas, heteroksiditas dan homogenitas. Berdasarkan hasil dari analisis persyaratan analisis dinyatakan bahwa data pendidikan, pendapatan dan jumlah anggota keluarga kecamatan Batang Anai telah memenuhi uji persyaratan analisis tersebut.

\section{Uji Normalitas}

Uji normalitas adalah untuk menguji apakah dalam model regresi, variabel terikat dan variabel bebas keduanya mempunyai distribusi normal atau tidak. Model regresi yang baik yaitu memiliki distribusi data normal atau mendekati normal. Hasil uji normalitas secara grafik Probability Plot dengan menggunakan SPSS 16.0 ditunjukkan dengan grafik dibawah ini : 


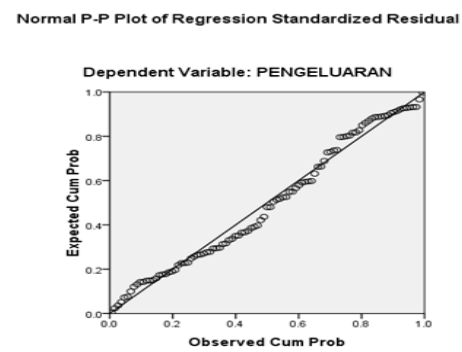

Gambar 1 Normal P-Plot

Sumber : Output SPSS, 2019 (data diolah)

Berdasarkan tampilan grafik berganda normal. Terlihat dari titik-titik Normal Plot diatas, dapat disimpulkan bahwa data yang digunakan untuk melakukan pengolahan regresi linear

2. Uji Multikolinearitas

Multikolinearitas dapat dilihat dari nilai Tolerance dan lawannya Variance Inflation Factor (VIF). Kedua ukuran ini menunjukkan setiap variabel manakah yang dijelaskan oleh variabel bebas lainnya. Jika nilai tolerance yang menyebar di sekitar garis diagonal dan penyebarannya mengikuti arah garis diagonal.

rendah sama dengan nilai VIF tinggi (karena VIF $=1 /$ tolerance $)$ dan menunjukkan adanya kolinearitas yang tinggi nilai cutoff yang umum digunakan adalah nilai tolerance diatas 0,10 atau sama dengan nilai VIF bawah 10 .

Tabel 3 Uji Multikolinearitas

\begin{tabular}{llll}
\multicolumn{4}{c}{ Coefficients $^{\mathrm{a}}$} \\
\hline & \multicolumn{2}{c}{ Collinearity Statistics } \\
\cline { 2 - 4 } & Model & Tolerance & VIF \\
\hline $1 \quad$ (Constant) & & \\
& & \\
PENDIDIKAN & .883 & 1.132 \\
PENDAPATAN & .846 & 1.182 \\
JUMLAH ANGGOTA & & \\
KELUARGA & .853 & 1.172 \\
\hline
\end{tabular}

a. Dependent Variable: PENGELUARAN

Sumber : Output SPSS, 2019 (data diolah)
Berdasarkan
tabel 3 Uji
3. Uji Heteroksiditas

multikolinearitas dapat disimpulkan tidak terdapat hubungan yang multikolinearitas karena nilai Tolerance dan VIF terlihat tidak ada nilai tolerance dibawah 0.10 dan nilai VIF tidak ada di atas 10.

Uji Heteroksiditas bertujuan untuk menguji apakah dalam model regresi terjadi ketidaksamaan varian dari residual satu pengamatan ke pengamatan yang lain. Jika varian dari 
residual satu pengamatan kepengamatan lain tetap maka disebut homoskedastisitas dan jika berbeda akan disebut heteroksiditas. Model regresi yang baik adalah model yang terjadiheteroksiditas.
Untuk mengetahui ada tidaknya heteroksiditas antar variable independen dapat dilihat dari grafik plot antara nilai prediksi variabel terikat dengan residualnya. Adapun grafik hasil pengujian heteroksiditas menggunakan SPSS 16.0 dapat dilihat dibawah ini:

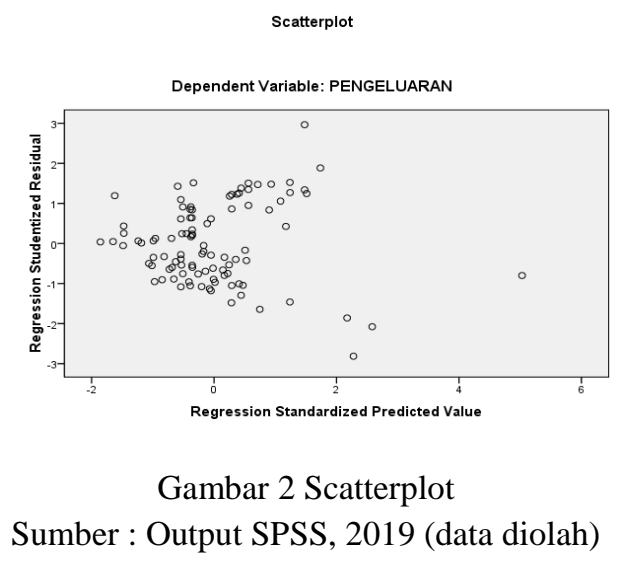

Berdasarkan gambar 2 dapat diketahui bahwa data (titik-titik) menyebar secara merata di atas dan dibawah garis nol, tidak berkumpul di satu tempat, serta tidak membentuk pola tertentu sehingga pada uji regresi ini tidak terjadi masalah heterokedastisitas. dan jumlah anggota keluarga secara bersama-sama berpengaruh signifikan terhadap pengeluaran. Yang artinya setiap perubahan yang terjadi pada variabel bebas akan berpengaruh terhadap pengeluaran keluarga di Kecamatan Batang Anai. Berikut tabel Output SPSS versi 16.0

Hasil penelitian menunjukkan bahwa variabel pendidikan, pendapatan

Tabel 4 HasilUjiRegresi Linear Berganda

\begin{tabular}{|c|c|c|c|c|}
\hline \multicolumn{5}{|c|}{ Coefficients $^{\mathrm{a}}$} \\
\hline & \multicolumn{2}{|c|}{$\begin{array}{l}\text { Unstandardized } \\
\text { Coefficients }\end{array}$} & \multirow[b]{2}{*}{$\mathrm{t}$} & \multirow[b]{2}{*}{ Sig. } \\
\hline Model & B & Std. Error & & \\
\hline $1 \quad$ (Constant) & $-1.275 \mathrm{E} 6$ & 933895.252 & $\begin{array}{c}- \\
1.366\end{array}$ & .175 \\
\hline PENDIDIKAN & 140295.802 & 58202.838 & 2.410 & .018 \\
\hline PENDAPATAN & .391 & .066 & 5.921 & .000 \\
\hline $\begin{array}{l}\text { JUMLAH } \\
\text { ANGGOTA } \\
\text { KELUARGA }\end{array}$ & 237582.969 & 144629.991 & 1.643 & .104 \\
\hline a. Depen & lent Variable: & PENGELUA & RAN & \\
\hline
\end{tabular}


Berdasarkan tabel 4 maka model regresi yang digunakan adalah sebagai berikut:

Selanjutnya untuk menguji pengaruh variabel independen secara parsial terhadap variabel dependen, dilakukan dengan cara melihat nilai probabilitas yang terdapat pada tabel 1.3 kolom Sig (signifikan). Jika nilai signifikansi lebih kecil dari 0.05 atau 5\% maka hipotesis yang diajukan diterima atau dikatakan signifikan. Sebaliknya jika nilai signifikansi lebih besar dari 0.05 atau 5\% maka hipotesis yang diajukan ditolak atau dikatakan tidak signifikan.

Berdasarkan tabel 4 pada kolom sig, dapat dilihat bahwa variabel pendidikan, pendapatan dan jumlah anggota keluarga memiliki pengaruh yang positif terhadap pengeluaran keluarga. Variable pendidikan dan pendapatan berpengaruh signifikan terhadap pengeluaran keluarga karena nilai signifikan nya lebih kecil dari 0,05. Variabel pendidikan memiliki nilai signifikan 0.018 sedangkan variabel pendapatan memiliki nilai signifikan 0,000, sedangkan variabel jumlah anggota keluarga tidak berpengaruh signifikan karena nilai signifikan nya 0,104 .

Variabel independen yang memiliki pengaruh paling dominan terhadap variabel dependen dalam penelitian ini adalah variabel pendapatan. Dapat dilihat dari tabel 1.3 pada kolom B dan kolom t, variabel pendapatan memiliki nilai paling besar yaitu 0.391 pada kolom B dan 5.921 pada kolom t. Hal tersebut mengindikasikan bahwa variabel
Pengeluaran $=-1,275 \mathrm{E} 6+140295,802$ Pendidikan + 0,391 Pendapatan + 237582,969 Jumlah Anggota Keluarga + e.........

pendapatan memiliki pengaruh yang paling dominan terhadap pengeluaran. Sehingga hipotesis yang menyatakan bahwa variabel pendapatan memiliki pengaruh paling dominan terhadap pengeluaran diterima.

\section{PENUTUP}

Dari hasil penelitian menunjukkan variabel pendidikan, pendapatan dan jumlah anggota keluarga secara bersamasama berpengaruh signifikan terhadap pengeluaran. Secara parsial variabel pendidikan dan pendapatan berpengaruh positif dan signifikan terhadap pengeluaran keluarga. Sedangkan jumlah anggota keluarga memiliki pengaruh positif namun tidak signifikan. Variabel yang memiliki pengaruh paling dominan adalah variabel pendapatan.

Pendidikan, diharapkan dengan meningkatnya tingkat pendidikan keluarga mampu meningkat pendapatan keluarga yang diharapkan mampu memenuhi kebutuhan anggota keluarga. Pada variabel pendapatan diharapkan anggota keluarga mampu bekerja sama dalam meningkatkan pendapatan keluarga dengan mengikutsertakan anggota keluarga yang telah memasuki usia kerja untuk bekerja. Untuk jumlah anggota keluarga diharapkan mampu di kurangi tingkat pertambahannya melalui berbagai program KB. Pendidikan dan pendapatan diharapkan mampu mengalami peningkatan untuk meningkatkan 
kesejahteraan keluarga di Kecamatan

Batang Anai.

\section{DAFTAR PUSTAKA}

Badan Pusat Statistik 2009. Pendapatan Nasional Indonesia. Jakarta.

Badan Pusat Statistik 2018. Kabupaten Padang Pariaman Dalam Angka 2018. BPS Padang Pariaman.

http:sumbar.bps.go.id
Undang-Undang Republik Indonesia No. 4 tahun 1992. Tentang Perumahan dan Permukiman. Jakarta.

Yusuf, A. Muri. 2013. Metode Penelitian Kuantitatif, Kualitatif dan Penelitian Gabungan.Jakart: Prenandamedia Group.

Widyanigsih, Erni. "Alokasi Pengeluaran dan Kesejahteraan Keluarga pada Keluarga Nelayan Bagan”. Jurnal. Departemen Ilmu Keluarga dan Konsumen. Institut Pertanian Bogor, Bogor. 